\title{
Separation of Kluyvera and Buttiauxella by Biochemical and Nucleic Acid Methods
}

\author{
F. GAVINI, ${ }^{1 *}$ D. IZARD,${ }^{1}$ C. FERRAGUT, ${ }^{1}$ J. J. FARMER III, ${ }^{2}$ AND H. LECLERC ${ }^{1}$
}

Institut National de la Santé et de la Recherche Médicale, Unité 146, Domaine du C.E.R.T.I.A., F-59650 Villeneuve d'Ascq Cedex, France, ${ }^{1}$ and Enteric Bacteriology Section, Center for Infections Diseases, Centers for Disease Control, Atlanta, Georgia $30333^{2}$

\begin{abstract}
We propose to maintain the genera Buttiauxella and Kluyvera, which are phenotypically similar, as separate genera in the Enterobacteriaceae. This separation is supported by the following findings: (i) strains of Kluyvera ascorbata and Kluyvera cryocrescens were related to Buttiauxella agrestis ATCC $33320^{\mathrm{T}}$ ( $\mathrm{T}$ $=$ type strain) at levels of 32 to $36 \%$ and 30 to $31 \%$, respectively, as determined by deoxyribonucleic acid relatedness (nitrocellulose filter method at $52.8^{\circ} \mathrm{C}$ ); (ii) the guanine-plus-cytosine ratios of Buttiauxella and Kluyvera deoxyribonucleic acids 48 to $50 \mathrm{~mol} \%$ and 55 to $57 \mathrm{~mol} \%$, respectively; and (iii) production of indole and lysine decarboxylase and fermentation of sucrose in 2 days could differentiate Kluyvera from Buttiauxella.
\end{abstract}

Kluyvera and Buttiauxella are two recently named genera in the family Enterobacteriaceae $(4,6)$. These two genera were proposed independently.

The purpose of this study was to compare strains of Kluyvera and Buttiauxella by using phenotypic characteristics, guanine-plus-cytosine $(\mathrm{G}+\mathrm{C})$ ratios, and deoxyribonucleic acid (DNA)-DNA hybridization so that a recommendation could be made for the classification of these organisms. From our findings we conclude that Kluyvera and Buttiauxella should remain separate genera.

Strains. The two complete sets of strains which we studied have been described previously $(4,6)$. Additional DNA hybridization experiments were done in France with three strains of Kluyvera ascorbata $\left(\mathrm{ATCC} 33433^{\mathrm{T}}[\mathrm{T}=\right.$ type strain], ATCC 33434 and ATCC 14236) and three strains of Kluyvera cryocrescens (ATCC $33435^{\circ}$, ATCC 14237, and ATCC 14238). The strains of Buttiauxella studied at the Centers for Disease Control were strains CUETM $77-167^{\mathrm{T}}(=$ ATCC $33320^{\mathrm{T}}=$ CIP $80-31^{\mathrm{T}}$ ), CUETM 78-19, CUETM 78-3, CUETM 78-34, and CUETM 78-8.

DNA-DNA hybridization and $\mathbf{G}+\mathrm{C}$ ratios. The hybridization method used has been described previously $(5,7)$. DNA extraction was performed by the method of Marmur (8). DNA reassociation was performed with nitrocellulose membrane filters by using the technique of De Ley and Tyjtgat (3). The optimal temperatures of renaturation were $52.8,57.4$, and $55.4^{\circ} \mathrm{C}$ for Buttiauxella agrestis ATCC $33320^{\mathrm{T}}, K$. ascorbata ATCC $33433^{\mathrm{T}}$, and $K$. cryocrescens ATCC $33435^{\mathrm{T}}$, respectively. The $\mathrm{G}+\mathrm{C}$ ratios of the
Kluyvera type strains were measured by the average melting point method, as described by De Ley (2) and as used previously by Ferragut et al. (6) to study 17 strains of Buttiauxella.

Biochemical reactions. Biochemical reactions were studied at both of our laboratories by methods described previously $(4,6)$.

The levels of relative binding of DNAs from $K$. ascorbata and $K$. cryocrescens strains to the DNA of $B$. agrestis type strain ATCC 33320 are presented in Table 1.

The strains within each of the species examined were closely related as determined by DNA-DNA hybridization; $K$. ascorbata strains were more than $80 \%$ related to each other $(26$ strains tested), $K$. cryocrescens strains were 75 to $96 \%$ related (10 strains), and $B$. agrestis strains were 82 to $96 \%$ related (17 strains). $K$. cryocrescens was 60 to $72 \%$ related to $K$. ascorbata $(4,6)$ (Table 1$)$.

The DNA values obtained for relatedness between B. agrestis (labeled DNA) and Kluyvera species were low ( 30 to $31 \%$ and 32 to $36 \%$ for $K$. cryocrescens and $K$. ascorbata, respectively).

Similar relatedness values between the two genera were obtained when DNAs from type strains of Kluyvera species were labeled (Table $1)$.

The $\mathrm{G}+\mathrm{C}$ ratios of $K$. cryocrescens ATCC 14237 and CDC 0546-78 and K. ascorbata ATCC $33433^{\mathrm{T}}$ and CDC $1058-74$, as determined by the buoyant density method (cesium chloride centrifugation), were $55,55,56$, and $57 \mathrm{~mol} \%$ respectively (Table 1). According to the method of Ferragut and Leclerc (7) and Ferragut et al. (5) 
TABLE 1. G $+\mathrm{C}$ content and DNA relatedness between species of Kluyvera and Buttiauxella

\begin{tabular}{|c|c|c|c|c|c|c|c|}
\hline \multirow{2}{*}{ Source of unlabeled DNA } & \multicolumn{2}{|c|}{$\begin{array}{l}\mathrm{G}+\mathrm{C} \text { content } \\
(\mathrm{mol} \%) \text {, as } \\
\text { determined by } \\
\text { the method of: }\end{array}$} & \multicolumn{5}{|c|}{ Relative binding (\%) to labeled DNA from: } \\
\hline & $\begin{array}{l}\text { Farm- } \\
\text { er } \\
\text { et al. }{ }^{a}\end{array}$ & $\begin{array}{l}\text { Ferra- } \\
\text { gut et } \\
\text { al. }^{b}\end{array}$ & $\begin{array}{l}\text { B. agrestis } \\
\text { ATCC } \\
33320^{\mathrm{T}}\end{array}$ & $\begin{array}{c}\text { K. ascor- } \\
\text { bata } \\
\text { ATCC } 14236^{c}\end{array}$ & $\begin{array}{c}\text { K. ascor- } \\
\text { bata } \\
{\text { ATCC } 33433^{\mathrm{T}}}^{\text {ATC }}\end{array}$ & $\begin{array}{c}\text { K. cryo- } \\
\text { crescens } \\
\text { ATCC } 14237^{c}\end{array}$ & $\begin{array}{c}\text { K. cryo- } \\
\text { crescens } \\
\text { ATCC } 33435^{\mathrm{T}}\end{array}$ \\
\hline \multicolumn{8}{|l|}{ K. ascorbata strains } \\
\hline $\begin{array}{l}\text { ATCC } 33433^{\mathrm{T}} \\
\left(=\operatorname{CDC} 648-74^{\mathrm{T}}\right)\end{array}$ & 56 & 58 & $36 \pm 7^{d}$ & 90 & 100 & 67 & 53 \\
\hline $\begin{array}{l}\text { ATCC } 33434 \\
\quad(=\text { CDC 2221-78) }\end{array}$ & & & $36 \pm 8$ & 93 & & 66 & \\
\hline $\begin{array}{l}\text { ATCC } 14236 \\
(=\text { CDC } 408-78)\end{array}$ & & & $32 \pm 6$ & 100 & & 65 & \\
\hline $\begin{array}{l}\text { CDC } 1058-74 \\
\text { Range for } 26 \text { strains }\end{array}$ & 57 & & $32-0$ & $\begin{array}{c}92 \\
69-100\end{array}$ & & $\begin{array}{r}03 \\
68 \\
55-72\end{array}$ & \\
\hline \multicolumn{8}{|l|}{$\begin{array}{l}K . \text { cryocrescens strains } \\
\text { ATCC } 33435^{\mathrm{T}}\end{array}$} \\
\hline $\begin{array}{l}\left(=\mathrm{CDC} 2065-78^{\mathrm{T}}\right) \\
\text { ATCC } 14237\end{array}$ & & 54 & $31 \pm 5$ & 69 & 52 & 94 & 100 \\
\hline$(=\mathrm{CDC} 409-78)$ & 55 & & $30 \pm 10$ & 62 & & 100 & \\
\hline ATCC 14238 & & & & & & & \\
\hline$(=\mathrm{CDC} 410-78)$ & & & $30 \pm 9$ & 65 & & 80 & \\
\hline CDC 0546-78 & 55 & & & 65 & & 80 & \\
\hline Range for 10 strains & & & & $60-69$ & & $75-100$ & \\
\hline $\begin{array}{l}\text { B. agrestis strains } \\
\text { ATCC } 33320^{\mathrm{T}}\end{array}$ & & & & & & & \\
\hline$\left(=\right.$ CUETM $\left.77-167^{\mathrm{T}}\right)$ & & 49 & $100^{e}$ & & 14 & & 14 \\
\hline CUETM 78-41 & & 48 & 87 & & 26 & & 31 \\
\hline CUETM 78-39 & & 47 & 94 & & 16 & & 15 \\
\hline CUETM 78-4 & & 48 & 89 & & 22 & & 22 \\
\hline CUETM 77-157 & & 48 & 91 & & 31 & & 18 \\
\hline CUETM 78-19 & & 48 & 96 & & 28 & & 35 \\
\hline Range for 17 strains & & $48-50$ & $82-94^{e}$ & & & & \\
\hline
\end{tabular}

${ }^{a}$ See reference 4 .

${ }^{b}$ See reference 5 .

c Data from Farmer et al. (4).

${ }^{d}$ Mean \pm standard deviation.

${ }^{e}$ Data from Ferragut et al. (6).

TABLE 2. Biochemical reactions of Kluyvera and Buttiauxella species

\begin{tabular}{|c|c|c|c|c|c|}
\hline \multirow[b]{2}{*}{ Test } & \multirow[b]{2}{*}{$\begin{array}{l}\text { Days of } \\
\text { incubation }\end{array}$} & \multirow[b]{2}{*}{ Source(s) of data $a^{a}$} & \multicolumn{3}{|c|}{ Reaction of: } \\
\hline & & & $\begin{array}{l}\text { B. agrestis } \\
\text { (17 strains) }\end{array}$ & $\begin{array}{l}\text { K. ascorbata } \\
\text { (73 strains) }\end{array}$ & $\begin{array}{l}\text { K. cryocrescens } \\
\text { (16 strains) }\end{array}$ \\
\hline Indole production & 2 & CDC + CUETM & $-b$ & + & $(+)$ \\
\hline L-Lysine decarboxylase & 2 & CDC + CUETM & - & + & V \\
\hline Ascorbate test ${ }^{c}$ & 2 & $\mathrm{CDC}$ & - & + & - \\
\hline $\begin{array}{l}\text { Growth and D-glucose fermen- } \\
\text { tation at } 5^{\circ} \mathrm{C}\end{array}$ & 21 & $\mathrm{CDC}$ & + & - & + \\
\hline Sucrose fermentation & 2 & CDC + CUETM & - & + & + \\
\hline D-Sorbitol fermentation & 2 & CDC + CUETM & - & $\mathrm{V}$ & V \\
\hline Tetrathionate reductase & 1 & CUETM & $\mathrm{V}$ & - & - \\
\hline
\end{tabular}

${ }^{a} \mathrm{CDC}$ indicates that the data are based on all of the Kluyvera strains examined and only five strains of Buttiauxella. CUETM indicates that data are based on all 17 strains of Buttiauxella and only 6 strains of Kluyvera. CDC + CUETM indicates that the data are based on the whole collection of strains.

$b+, 90$ to $100 \%$ positive; $(+), 75$ to $89.9 \%$ positive; $\mathrm{V}, 25.1$ to $74.9 \%$ positive;,- 0 to $10 \%$ positive.

'See reference 4. 
the $\mathrm{G}+\mathrm{C}$ contents of the DNAs of Kluyvera species are very similar $(54 \mathrm{~mol} \%$ for $K$. cryocrescens ATCC $33435^{\mathrm{T}}$ and $58 \mathrm{~mol} \%$ for $K$. ascorbata ATCC $33433^{\mathrm{T}}$ ).

Ferragut et al. (5) studied the $\mathrm{G}+\mathrm{C}$ contents of 17 strains of $B$. agrestis, and the mean value was $49 \mathrm{~mol} \%$. Therefore, the $\mathrm{G}+\mathrm{C}$ contents of the DNAs of Kluyvera species were different enough from those of $B$. agrestis to differentiate the two groups.

The separation of Buttiauxella and Kluyvera was confirmed by the low level of DNA relatedness between members of these two genera.

In addition to the genomic differences between Kluyvera and Buttiauxella, there were also some phenotypic differences (Table 2). Most Kluyvera strains produced indole and Llysine decarboxylase (Møller) and rapidly fermented sucrose. Strains of Buttiauxella were negative or exhibited delayed reactions for these properties.

We believe that the genomic and phenotypic differences between these genera are such that continued separation is warranted at this time, pending further study.

\section{LITERATURE CITED}

1. Brenner, D. J., A. C. McWhorter, J. K. Leete Knutson, and A. G. Steigerwalt. 1982. Escherichia vulneris: a new species of Enterobacteriaceae associated with human wounds. J. Clin. Microbiol, 15:1133-1140.

2. De Ley, J. 1970. Reexamination of the association between melting point, buoyant density and chemical base composition of deoxyribonucleic acid. J. Bacteriol. 101:738-754.

3. De Ley, J., and R. Tyjtgat. 1970. Evaluation of membrane filter methods for DNA-DNA hybridization. Antonie van Leeuwenhoek J. Microbiol. Serol. 36:461-474.

4. Farmer, J. J., G. R. Fanning, G. P. Huntley-Carter, B. Holmes, F. W. Hickman, C. Richard, and D. J. Brenner. 1981. Kluyvera, a new (redefined) genus in the family Enterobacteriaceae: identification of Kluyvera ascorbata sp. nov. and Kluyvera cryocrescens sp. nov. in clinical specimens. J. Clin. Microbiol. 13:919-933.

5. Ferragut, C., F. Gavini, D. Izard, and H. Leclerc. 1978. Etude du \% GC dans un groupe d'entérobactéries $\mathrm{H}_{2} \mathrm{~S}^{-}$ apparentées au genre Citrobacter. Can. J. Microbiol. 24:473-479

6. Ferragut, C., D. Izard, F. Gavini, B. Lefebvre, and $H$. Leclerc. 1981. Buttiauxella, a new genus of the family Enterobacteriaceae. Zentralbl. Bakteriol. Parasitenkd. In fektionskr. Hyg. Abt. 1 Orig. Reihe C 2:33-44.

7. Ferragut, C., and H. Leclerc. 1976. Etude comparative des méthodes de détermination du T $m$ de l'ADN bactérien. Ann. Microbiol. (Paris) 127A:233-235.

8. Marmur, J. 1961. A procedure for the isolation of deoxyribonucleic acid from microorganisms. J. Mol. Biol. 3:208218 . 